\title{
Determination of energy and protein requirements for crossbred Holstein $\times$ Gyr preweaned dairy calves
}

\author{
A. L. Silva, ${ }^{*}$ M. I. Marcondes, ${ }^{, 1}$ E. Detmann, ${ }^{*}$ M. M. Campos,† F. S. Machado,† S. C. Valadares Filho, ${ }^{*}$ \\ M. M. D. Castro, ${ }^{*}$ and J. Dijkstrał \\ *Department of Animal Science, Universidade Federal de Viçosa, 36570-000 Viçosa, Minas Gerais, Brazil \\ †Empresa Brasileira de Pesquisa Agropecuária (EMBRAPA), 36038-330 Juiz de Fora, Minas Gerais, Brazil \\ $\ddagger$ Animal Nutrition Group, Wageningen University, PO Box 338, 6700 AH Wageningen, the Netherlands
}

\begin{abstract}
The objective was to quantify the energy and protein nutritional requirements of Holstein $\times$ Gyr crossbred preweaned dairy calves until $64 \mathrm{~d}$ of age. Thirty-nine Holstein $\times$ Gyr crossbred male calves with an average initial live weight (mean \pm SEM; for all next values) of $36 \pm 1.0 \mathrm{~kg}$ were used. Five calves were slaughtered at $4 \mathrm{~d}$ of life to estimate the animals' initial body composition (reference group). The remaining 34 calves were distributed in a completely randomized design in a 3 $\times 2$ factorial arrangement consisting of 3 levels of milk $(2,4$, or $8 \mathrm{~L} / \mathrm{d}$ ) and 2 levels of starter feed (presence or absence in diet). At 15 and $45 \mathrm{~d}$ of life, 4 animals from each treatment were subjected to digestibility trials with total collection of feces (for $72 \mathrm{~h}$ ) and urine (for 24 h). At $64 \mathrm{~d}$ of age, all animals were slaughtered, their gastro-intestinal tract was washed to determine the empty body weight (EBW; $\mathrm{kg}$ ), and their body tissues were sampled for subsequent analyses. The net energy requirement for maintenance was estimated using an exponential regression between metabolizable energy intake and heat production (both in Mcal/EBW ${ }^{0.75}$ per d) and was $74.3 \pm 5.7 \mathrm{kcal} / \mathrm{EBW}^{0.75}$ per d, and was not affected by inclusion of starter feed in the diet. The metabolizable energy requirement for maintenance was determined at the point of zero energy retention in the body and was $105.2 \pm 5.8 \mathrm{kcal} / \mathrm{EBW}^{0.75}$ per $\mathrm{d}$. The net energy for gain was estimated using the EBW and the empty body gain $(\mathrm{EBG} ; \mathrm{kg} / \mathrm{d})$ as $0.0882 \pm 0.0028 \times$ $\mathrm{EBW}^{0.75} \times \mathrm{EBG}^{0.9050 \pm 0.0706}$. The metabolizable energy efficiency for gain $\left(\mathrm{k}_{\mathrm{g}}\right)$ of the milk was $57.4 \pm 3.45 \%$, and the $\mathrm{k}_{\mathrm{g}}$ of the starter feed was $39.3 \pm 2.09 \%$. The metabolizable protein requirement for maintenance was $3.52 \pm 0.34 \mathrm{~g} / \mathrm{BW}^{0.75}$ per $\mathrm{d}$. The net protein required for each kilogram gained was estimated as $119.1 \pm 32.9$ $\times \mathrm{EBW}^{0.0663 \pm 0.059}$. The metabolizable protein efficiency
\end{abstract}

Received March 21, 2016.

Accepted October 16, 2016.

${ }^{1}$ Corresponding author: marcos.marcondes@ufv.br for gain was $77 \pm 8.5 \%$ and was not affected by inclusion of starter feed in the diet. In conclusion, the energy efficiency for gain of milk is higher than that of starter and the net protein required per unit protein gain increases with empty body weight.

Key words: maintenance, milk, retained energy, starter feed

\section{INTRODUCTION}

In recent years, several research studies have demonstrated the importance of the nutritional management of calves within the dairy-cattle production system, as this period has an effect on animals' productive life (Moallem et al., 2010; Khan et al., 2011; Soberon et al., 2012). For example, Bach and Ahedo (2008) found a positive correlation between ADG of calves between 10 and $65 \mathrm{~d}$ of age and first-lactation milk yield. Although Gelsinger et al. (2016) suggested a lower influence of pre-weaning nutritional management on the first-lactation milk yield, they also observed a positive relationship between the intake of milk and starter feed during the pre-weaning phase and the first-lactation milk yield. Yet, studies addressing the nutritional requirements in terms of energy and protein of calves during the preweaned phase are still rather scarce.

Among the most complete publications on nutritional requirements of cattle are NRC (2001), AFRC (1993), INRA (2007), and CSIRO (2007). The NRC (2001) is notably the most widely used to access the nutritional requirements of calves. Nevertheless, the data presented by the NRC (2001) have several limitations as indicated by NRC (2001) itself. For instance, to calculate the requirements of energy it is recommended to use current genotypes to refine the energy required for weight gain, whereas a large portion of the data used by NRC (2001) derives from the study of Holmes and Davey (1976). Another important aspect is the genetic pattern of these animals, given that the majority of data available in the literature was generated with Bos taurus animals. However, it is known that Bos taurus 
$\times$ Bos indicus crossbred animals are widely scattered around the world, and for instance, the Brazilian dairy herd consists largely of Holstein $\times$ Zebu crossbred cattle (Ruas et al., 2006). In this context, Chizzotti et al. (2007) and Valadares Filho et al. (2010) demonstrated breed effects on nutritional requirements for beef cattle, and similar differences may be present for preweaned dairy calves.

In our previous study (Silva et al., 2015), we demonstrated that the inclusion of starter feed is capable of improving performance (increased weight gain and $\mathrm{N}$ retention) and changes body composition (increased fat content). Thus, as the diet composition may influence nutrient requirements (AFRC, 1993), we hypothesized that the presence or absence of starter feed in the diet influences energy and protein requirements, and further hypothesized that the nutritional requirements obtained by international systems, especially those suggested by the NRC (2001), are not suitable for Holstein $\times$ Gyr reared under tropical conditions. Thus, the present analysis was carried out aiming to quantify the nutritional requirements of energy and protein for Holstein $\times$ Gyr crossbred preweaned dairy calves until $64 \mathrm{~d}$ of age.

\section{MATERIALS AND METHODS}

The experiment was approved by the ethics committee for animal use at Universidade Federal de Viçosa (Viçosa, MG, Brazil), under protocol no. 049/2012.

\section{Animals, Digestibility Trial, Slaughter, and Chemical Analysis}

Details about animals, treatments, feeding, digestibility trials, slaughter, and chemical analysis are presented by Silva et al. (2015). Briefly, 39 uncastrated crossbred male calves were used $(1 / 2$ to $3 / 4$ Holstein $\times$ Gyr $)$ with an average initial BW of $36 \pm 1.0 \mathrm{~kg}$ (mean $\pm \mathrm{SEM}$; for all of the next values). Of the total, 5 animals were designated as reference group and slaughtered at $4 \mathrm{~d}$ of life. The other calves were distributed in a completely randomized design in a $3 \times 2$ factorial arrangement consisting of 3 levels of milk and 2 levels of starter. Six treatments were subsequently formed: $2 \mathrm{~L}$ of milk daily $(\mathrm{n}=4) ; 4 \mathrm{~L}$ of milk daily $(\mathrm{n}=6) ; 8 \mathrm{~L}$ of milk daily $(\mathrm{n}=$ 6); $2 \mathrm{~L}$ of milk daily plus free access to the starter feed $(\mathrm{n}=6) ; 4 \mathrm{~L}$ of milk daily plus free access to the starter feed $(\mathrm{n}=6)$; and $8 \mathrm{~L}$ of milk daily plus free access to the starter feed $(\mathrm{n}=6$; Table 1$)$.

At 15 and $45 \mathrm{~d}$ of life, 4 animals from each treatment were subjected to digestibility trials with total fecal and urine collection for 72 and $24 \mathrm{~h}$, respectively. At the end of the experiment all animals were slaughtered after fasting for $14 \mathrm{~h}$ and subsequently the gastro-intestinal tract was washed to determine empty body weight (EBW). After that, a composite sample of blood, hides, head, paws, various organs, and viscera was formed and ground for $20 \mathrm{~min}$ in an industrial grinder and then named noncarcass components. The carcasses were weighed and each right half-carcass was fully ground in an industrial grinder, generating a carcass-components sample.

Samples of feeds, feces, and body components were analyzed for DM, ash, CP, and ether extract (EE). The samples of feces and starter feed were also evaluated for their concentration of NDF corrected for ash and protein $\left(\mathrm{NDF}_{\mathrm{ap}}\right)$, and urine was analyzed for $\mathrm{N}$ content. Further details of chemical analyses are described by Silva et al. (2015).

\section{Calculations}

Nonfiber carbohydrates were calculated according to the model proposed by Detmann and Valadares Filho (2010):

$$
\mathrm{NFC}=1,000-\left(\mathrm{CP}+\mathrm{NDF}_{\mathrm{ap}}+\mathrm{EE}+\mathrm{CA}\right),
$$

where $\mathrm{CA}=$ crude ash and all values are in grams per kilogram.

The digestible energy (DE) of the diet was calculated by multiplying the digestible fraction of each energy component by its respective energy value (NRC, 2001) as

$$
\begin{aligned}
& \mathrm{DE}=(5.6 \times \mathrm{dCP})+(9.4 \times \mathrm{dEE})+(4.2 \times \mathrm{dNFC}) \\
& +\left(4.2 \times \mathrm{dNDF}_{\mathrm{ap}}\right),
\end{aligned}
$$

Table 1. Components of starter feed and chemical composition of starter feed and milk ${ }^{1}$

\begin{tabular}{lcc}
\hline Item & Starter feed & Milk \\
\hline Composition, g/kg & 324.9 & - \\
Soybean meal & 626.4 & - \\
Corn meal & 30.9 & - \\
Wheat bran & 17.8 & - \\
Minerals & & \\
Chemical composition, g/kg & 892.2 & 114.0 \\
$\mathrm{DM}^{2}$ & 959.8 & 937.4 \\
$\mathrm{OM}^{3}$ & 191.5 & 256.6 \\
$\mathrm{CP}^{3}$ & 25.5 & 285.0 \\
Ether extract $^{3}$ & 130.7 & - \\
$\mathrm{NDF}^{3}$ & 611.0 & 395.8 \\
NFC $^{3}$ &
\end{tabular}

${ }^{1}$ Data originally published, and with more information, in Silva et al (2015).

${ }^{2}$ As-fed basis.

${ }^{3}$ Dry matter basis. 
where $\mathrm{DE}$ is in megacalories per kilogram, $\mathrm{dCP}=$ digestible crude protein concentration $(\mathrm{kg} / \mathrm{kg})$, dEE $=$ digestible ether extract concentration $(\mathrm{kg} / \mathrm{kg}), \mathrm{dNFC}_{\text {ap }}$ $=$ digestible nonfibrous carbohydrate concentration $(\mathrm{kg} / \mathrm{kg})$, and $\mathrm{dNDF}_{\text {ap }}=$ digestible neutral detergent fiber corrected for ash and protein concentration $(\mathrm{kg} /$ $\mathrm{kg})$.

The concentration of ME of the diet was calculated according to the equation proposed by the NRC (2001) for diets rich in fat:

$$
\mathrm{ME}=[(1.01 \times \mathrm{DE})-0.45]+[0.0046 \times(\mathrm{EE}-3)],
$$

where $\mathrm{ME}$ and $\mathrm{DE}$ are in megacalories per kilogram, and $\mathrm{EE}$ is in \% of DM.

To determine metabolic fecal nitrogen (MFN), we used the daily $\mathrm{N}$ intake and daily apparent $\mathrm{N}$ absorbed from each animal at the 2 digestibility trials at 15 and $45 \mathrm{~d}$ of life. The MFN was assumed to be the negative intercept $\left(\beta_{0}\right)$ of the regression between the daily apparent $\mathrm{N}$ absorbed and the daily $\mathrm{N}$ intake, according to the following model (Kohn et al., 2005):

$$
\mathrm{ANA}=\beta_{0}+\beta_{1} \times \mathrm{NI},
$$

where $\mathrm{ANA}=$ apparent $\mathrm{N}$ absorbed $\left(\mathrm{g} / \mathrm{BW}^{0.75}\right.$ per $\left.\mathrm{d}\right)$, $\mathrm{NI}=\mathrm{N}$ intake $\left(\mathrm{g} / \mathrm{BW}^{0.75}\right.$ per $\left.\mathrm{d}\right)$, and $\beta_{0}$ and $\beta_{1}$ are regression parameters.

The true $\mathrm{N}$ excretion was calculated as the difference between the apparent fecal $\mathrm{N}$ excretion and MFN. The metabolizable protein intake (MPI) was calculated as the difference between the daily $\mathrm{N}$ intake and the true daily $\mathrm{N}$ excretion, multiplied by the factor 6.25 , considering the average relation between milk and starter feed for each animal.

The body energy content was obtained from the body contents of protein and fat and their respective caloric equivalents of 5.7 and 9.5 (ARC, 1980):

$$
\mathrm{EC}=5.7 \times \mathrm{CP}_{\mathrm{EB}}+9.5 \times \mathrm{EE}_{\mathrm{EB}}
$$

where $\mathrm{EC}=$ body energy content $(\mathrm{Mcal}) ; \mathrm{CP}_{\mathrm{EB}}=$ crude protein content in the empty body $(\mathrm{kg}) ; \mathrm{EE}_{\mathrm{EB}}=$ ether extract content in the empty body $(\mathrm{kg})$.

To estimate the EBW from the BW of the animals, the ratios between the EBW and BW of the animals subjected to the treatments were calculated. In addition, to estimate the empty body gain (EBG) from the ADG, ratios between EBG and ADG was used. The initial EBW and initial body composition were estimated by using data from the reference group.

The net energy requirement for maintenance $\left(\mathbf{N E}_{\mathbf{m}}\right)$ was assumed to be the intercept $\left(\beta_{0}\right)$ of the equation of exponential regression between ME intake and heat production (Ferrell and Jenkins, 1998a,b):

$$
\mathrm{HP}=\beta_{0} \times e^{\beta_{1} \times \mathrm{MEI}},
$$

where $\mathrm{HP}=$ heat production $\left(\mathrm{Mcal} / \mathrm{EBW}^{0.75}\right.$ per $\left.\mathrm{d}\right)$, MEI $=$ metabolizable energy intake $\left(\mathrm{Mcal} / \mathrm{EBW}^{0.75}\right.$ per $d$ ), and $\beta_{0}$ and $\beta_{1}$ are equation parameters. Heat production was calculated as the difference between the metabolizable energy intake (MEI) and the retained energy (RE), where retained energy was calculated from the increase in body fat and body protein composition and their respective caloric values (Equation [5]). By the iterative method, the metabolizable energy requirement for maintenance ( $\mathbf{M E}_{\mathbf{m}}$, expressed as Mcal/ $\mathrm{EBW}^{0.75}$ per d) was determined as the point where the MEI and the heat production are equal [i.e., the point at which there is no energy retention in the body (Chizzotti et al., 2007)]. The efficiency of use of ME for maintenance $\left(\boldsymbol{k}_{m}\right)$ was obtained as the ratio between the net and ME requirements for maintenance.

To relate RE to EBW and EBG, parameters were estimated following the model proposed by Garrett (1980):

$$
\mathrm{RE}=\beta_{0} \times \mathrm{EBW}^{0.75} \times \mathrm{EBG}^{\beta_{1}},
$$

where $\mathrm{RE}$ is in megacalories per day, $\mathrm{EBW}^{0.75}=$ average metabolic EBW (kg), EBG is in kilograms per day, and $\beta_{0}$ and $\beta_{1}$ are equation parameters.

The efficiency of use of the metabolizable energy for weight gain $\left(\boldsymbol{k}_{\boldsymbol{g}}\right.$; expressed as \%), was assumed to be the slope coefficient $\left(\beta_{1}\right)$ of the regression of the RE as a function of the MEI, according to Ferrell and Jenkins (1998b):

$$
\mathrm{RE}=\beta_{0}+\beta_{1} \times \mathrm{MEI}
$$

where RE and MEI are in megacalories/EBW ${ }^{0.75}$ per day, and $\beta_{0}$ and $\beta_{1}$ are equation parameters.

The net protein requirement for maintenance was calculated as the negative intercept of the regression between the retained protein (RP) and the MPI, according the following model based on Chizzotti et al. (2007), but with MPI as the independent variable:

$$
\mathrm{RP}=\beta_{0}+\beta_{1} \times \mathrm{MPI}
$$

where RP and MPI are in grams/EBW ${ }^{0.75}$ per day, and $\beta_{0}$ and $\beta_{1}$ are regression parameters.

The metabolizable protein requirement for maintenance was calculated according to Wilkerson et al. 
(1993), in which the MPI was related to the ADG of the animals:

$$
\mathrm{MPI}=\beta_{0}+\beta_{1} \times \mathrm{ADG},
$$

where MPI is in grams per day, ADG is in kilograms per day, and $\beta_{0}$ and $\beta_{1}$ are regression parameters.

The metabolizable protein requirements for maintenance $\left(\mathbf{M P}_{\mathbf{m}}\right)$ were estimated as (NRC, 2000)

$$
\mathrm{MP}_{\mathrm{m}}=\frac{\beta_{0}}{\mathrm{BW}_{\mathrm{a}}^{0.75}}
$$

where $\mathrm{MP}_{\mathrm{m}}$ is in grams $/ \mathrm{BW}^{0.75}$ per day, $\beta_{0}=$ intercept of Equation [10], and $\mathrm{BW}_{\mathrm{a}}{ }^{0.75}=$ average metabolic $\mathrm{BW}$ $(\mathrm{kg})$.

The efficiency of use of MP for maintenance was obtained as the ratio between net and MP requirements for maintenance. To calculate the net protein requirement for gain $\left(\mathbf{N P}_{\mathbf{g}}\right)$, first, the body protein content as a function of the EBW of each treatment was estimated by an allometric model according to Fortin et al. (1980):

$$
\mathrm{BP}=\beta_{0} \times \mathrm{EBW}^{\beta_{1}}
$$

where $\mathrm{BP}=$ body protein $(\mathrm{kg})$, EBW is in kilograms, and $\beta_{0}$ and $\beta_{1}$ are regression parameters.

Based on the parameters of Equation [12], the requirements of protein per kilogram of EBW were estimated by the first derivative of Equation [12], as described by Chizzotti et al. (2007):

$$
\mathrm{NP}_{\mathrm{g}}=\beta_{0} \times \beta_{1} \times \mathrm{EBW}^{\beta_{1}-1}
$$

where $\mathrm{NP}_{\mathrm{g}}$ is in grams/EBG per day, EBW is in kilograms, and $\beta_{0}$ and $\beta_{1}$ are regression parameters.

Finally, the efficiency of use of metabolizable protein for gain ( $\boldsymbol{k}$, expressed in \%) was calculated as the slope of the regression between the RP and MPI (Equation $[9])$.

\section{Statistical Analyses}

The parameters of the linear models were tested using the PROC MIXED procedure and nonlinear regressions were adjusted by the PROC NLMIXED procedure of SAS Institute (version 9.3, SAS Institute Inc., Cary, $\mathrm{NC}$ ). The inclusion of starter feed was tested at the intercept and slope of all models, and when the parameters were equivalent $(P>0.05)$, a combined equation was generated. A linear equation system was set up to estimate $k_{g}$ and fecal excretion of metabolic $\mathrm{N}$ of the starter feed, considering the $k_{q}$ or fecal excretion metabolic $\mathrm{N}$ obtained for the diets with and without starter feed, and the average ratio between milk and starter feed on the basis of the DM from the animals' diet. Observations with studentized residuals above 2.5 or below -2.5 were considered outliers and thus excluded from the models. For all statistical procedures, a significance level of $5 \%$ was adopted.

\section{RESULTS AND DISCUSSION}

\section{Relationship Between BW and EBW and Between $A D G$ and $E B G$}

The relationship between BW and EBW was not affected by milk allowance $(P>0.533)$ nor starter feed inclusion $(P>0.287$; Supplemental Table S1, https:// doi.org/10.3168/jds.2016-11197). Thus, a single model, without intercept (intercept nonsignificant, $P>0.751$ ) was used to adjust the EBW in function of BW:

$$
\begin{aligned}
& \mathrm{EBW}=0.945 \pm 0.0065 \times \mathrm{BW} \\
& \left(\mathrm{R}^{2}=0.998 ; \mathrm{RMSE}=2.619\right),
\end{aligned}
$$

where EBW and BW are expressed in kilograms and RMSE $=$ root mean squared error.

Similarly, the relationship between ADG and EBG was not affected by starter feed inclusion $(P>0.625)$ nor by milk allowance $(P>0.429)$. Thus, a single model without intercept $(P>0.316)$ was used:

$$
\begin{aligned}
& \mathrm{EBG}=0.908 \pm 0.0132 \times \mathrm{ADG} \\
& \left(\mathrm{R}^{2}=0.978 ; \mathrm{RMSE}=0.044\right),
\end{aligned}
$$

where EBG and ADG are expressed in kilograms per day.

The use of EBW and EBG instead of BW and ADG generally leads to a more precise nutrient requirement estimation, once the effects of gut contents are removed and only organs without digestive contents and tissues are considered for chemical analyses and calculations (Chizzotti et al., 2008).

\section{Energy Requirements}

Requirements and Efficiency of Use of Energy for Maintenance. The influence of starter feed supply on the energy requirement for maintenance was tested and no differences were found $(P>0.32)$. Thus, a combined equation was formulated, wherein the net energy required for maintenance was $74.3 \mathrm{kcal} / \mathrm{EBW}^{0.75}$ per d (or $71.2 \mathrm{kcal} / \mathrm{BW}^{0.75}$ per d): 


$$
\begin{aligned}
& \mathrm{HP}=0.0743 \pm 0.057 \times \mathrm{e}^{3.4453 \pm 0.3580 \times \mathrm{MEI}} \\
& \left(\mathrm{R}^{2}=0.796 ; \mathrm{RMSE}=0.032\right)
\end{aligned}
$$

where HP and MEI are in $\mathrm{Mcal} / \mathrm{EBW}^{0.75}$ per d.

The $\mathrm{NE}_{\mathrm{m}}$ found in this study is lower than the $86 \mathrm{kcal} /$ $\mathrm{BW}^{0.75}$ per d reported by the NRC (2001). Similarly, others reported lower $\mathrm{NE}_{\mathrm{m}}$ requirements of mature Bos indicus crossbreds than pure Bos taurus (e.g., Chizzotti et al., 2007). However, the $\mathrm{ME}_{\mathrm{m}}$, calculated by the iterative method, was $105.2 \pm 5.8 \mathrm{kcal} / \mathrm{EBW}^{0.75}$ per d or $100.8 \mathrm{kcal} / \mathrm{BW}^{0.75}$ per d; this value is similar to many results found in the literature [e.g., ARC (1980), Arieli et al. (1995), Gerrits et al. (1996), and NRC (2001), with values of $102,103,107$, and $104 \mathrm{kcal} / \mathrm{BW}^{0.75}$ per $\mathrm{d}$, respectively].

The $\mathrm{NE}_{\mathrm{m}}$ is related to the fulfillment of basal functions including maintenance requirements of internal organs and protein turnover (Valadares Filho et al., 2010), and can be described as a direct and almost exclusive function of the animal metabolism. Therefore, the divergence between the $\mathrm{NE}_{\mathrm{m}}$ values shown in this study and those found in the literature, which was not observed for $\mathrm{ME}_{\mathrm{m}}$, may be explained by a difference in the efficiency of use of the ME for maintenance.

No effect $(P>0.314)$ was found of starter feed inclusion on $k_{m}$, and a single value of $70.6 \%$ was obtained. The NRC (2001) suggests that milk and starter feed are used with different efficiencies for maintenance: 86 and $75 \%$, respectively. Additionally, the NRC (2001) considers a fixed ratio of 60:40 between milk and starter feed in the diet, where milk is responsible for $68 \%$ and starter feed is responsible for $32 \%$ of the energy supply, which generates an average value of $82.5 \%$ for $k_{m}$. In addition to the absence of difference in $k_{m}$ for milk and starter feed in the present study, the $k_{m}$ values suggested by the NRC may be overestimated. Schrama et al. (1992) and Arieli et al. (1995) found values close to $68 \%$, whereas ARC (1980) suggests a $k_{m}$ varying from 72 to $77 \%$, which are closer to the values found in this study.

Requirements and Efficiency of Use of Energy for Gain. The model proposed to estimate the net energy requirement for gain was as follows:

$$
\begin{aligned}
& \mathrm{RE}=0.0882 \pm 0.0028 \times \mathrm{EBW}^{0.75} \times \mathrm{EBG}^{0.9050 \pm 0.0706} \\
& \left(\mathrm{R}^{2}=0.954 ; \mathrm{RMSE}=0.127\right)
\end{aligned}
$$

where $\mathrm{RE}$ is in megacalories per day, $\mathrm{EBW}^{0.75}$ is in kilograms, and EBG is in kilograms per day.

The requirements calculated by the model suggested by Toullec (1989) and adopted by NRC (2001) are higher than those calculated in this study for all weight ranges and in particular low weights (Figure 1). Diaz et al. (2001) observed an overestimate of the energy requirements for gain using the model proposed by Toullec (1989), which may be associated with the use of animals with a high live weight and fed low-quality feeds, which may increase fat deposition and thus overestimate net energy requirement for gain (Diaz et al., 2001). The RE as predicted by the model of Fonseca et al. (2012) has a similar response to the RE predicted by the present equation. The equation suggested by Diaz et al. $\left(2001 ; \mathrm{RE}=\mathrm{EBW}^{0.223} \times \mathrm{EBG}^{1.32}\right)$ suggests a $\mathrm{RE}$ lower than this study for animals heavier than $60 \mathrm{~kg}$ of BW, which may be related to the gain composition of the animals used in the different experiments, insofar as higher gains may mean relatively greater fat deposition and consequently greater energy requirements (Valadares Filho et al., 2010). Overall, these results also show the importance of assessing the effect that breed differences have on the animals' nutritional requirements, given that the data obtained in this study with Holstein $\times$ Gyr crossbred animals are similar to those found by Fonseca et al. (2012) with Nellore calves, whereas Toullec (1989) used Holstein calves. In line with this explanation, AFRC (1993) estimates the net energy requirements for a calf with $30 \mathrm{~kg}$ of BW and ADG of $0.5 \mathrm{~kg} / \mathrm{d}$ as $0.6 \mathrm{Mcal} / \mathrm{d}$. Considering an animal in the same situation, the estimates generated by the model proposed in the present study would be approximately $0.53 \mathrm{Mcal} / \mathrm{kg}$ of $\mathrm{ADG}$, whereas the value calculated by NRC (2001) would be $0.84 \mathrm{Mcal} /$ $\mathrm{kg}$ of $\mathrm{ADG}$.

Regarding the efficiency of use of the metabolizable energy for gain $\left(k_{g}\right)$, significant differences $(P<0.01)$ were obtained for the groups that received only milk (Figure 2A) or milk and starter feed (Figure 2B); these values were $57.4 \pm 3.45$ and $51.6 \pm 3.98 \%$, respectively. Based on the animals' actual intake of milk and starter feed, and applying the values of 57.4 and $51.6 \%$ for diets without and with starter feed, the gain efficiency from starter feed only was calculated as $39.3 \pm 2.09 \%$. Considering mixed diets, the NRC (2001) suggests a $k_{g}$ of the order of $65.2 \%$, whereas Gerrits et al. (1996) and Blome et al. (2003) found a $k_{g}$ of $58 \%$, and the ARC (1980) suggests that $k_{g}$ is between 50 and 59\%. With the exception of NRC (2001), these values are all consistent with the values obtained in the present study; yet, none of these studies discriminates differences between milk and starter feed. The efficiency of use of the metabolizable energy is influenced by several factors such as the environment, the muscle work performed by the animal (Signoretti et al., 1999), and the metabolizability of the diet [i.e., the ratio of ME to gross energy (ARC, 1980)]. Garrett and Johnson (1983) stated that 


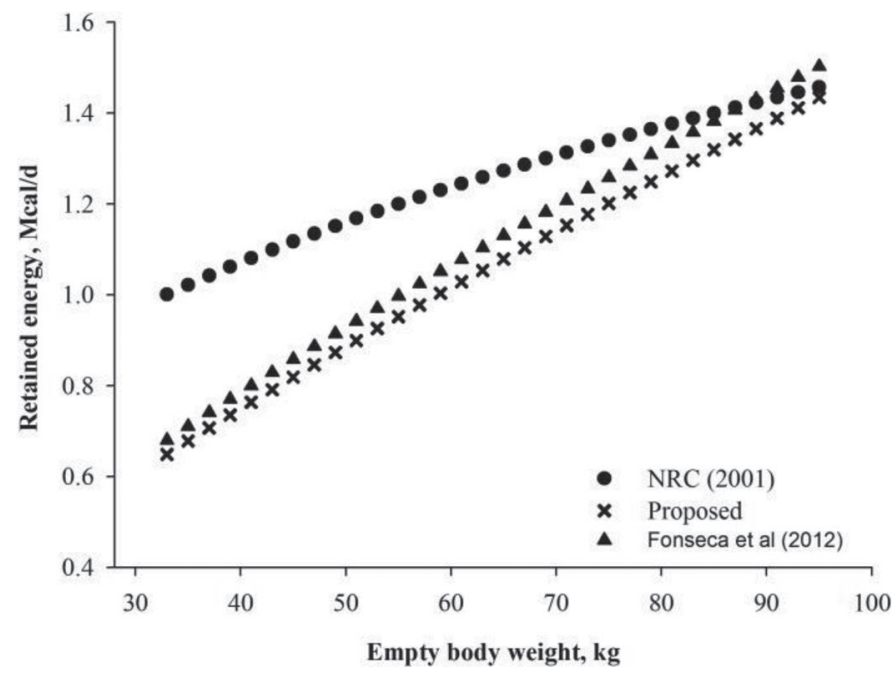

Figure 1. Comparison among the prediction models for retained energy $(\mathrm{RE})$ proposed by $\mathrm{NRC}(2001)\left[\mathrm{RE}=\left(0.84 \times \mathrm{BW}^{0.355} \times \mathrm{ADG}^{1.2}\right)\right.$ $\times 0.69]$, the model proposed in this study $\left[\mathrm{RE}=0.0882 \times \mathrm{EBW}^{0.7}\right.$ $\left.\times \mathrm{EBG}^{0.9050}\right]$, and Fonseca et al. $(2012)\left[\mathrm{RE}=0.0932 \times \mathrm{EBW}^{0.75} \times\right.$ $\mathrm{EBG}^{0.9175}$ ] considering an empty body gain $(\mathrm{EBG})$ of $0.5 \mathrm{~kg} / \mathrm{d}$. For the model proposed by NRC (2001), to convert empty BW (EBW) to BW and $\mathrm{EBG}$ to $\mathrm{ADG}$, Equations [14] and [16] were used, respectively.

the metabolizability of the diet directly influences the efficiencies of energy use, but its effect is more pronounced on the efficiency of use of ME for gain than on efficiency of use of ME for maintenance, and this response was also observed in the present study. This result may be related to the composition of the feeds, given that the ME contents of milk and starter feed are 4.8 and $3.6 \mathrm{Mcal} / \mathrm{kg}$ of DM. In view of the likely differences between the energy levels of milk and milk replacers, studies should be conducted to determine the efficiencies of use of energy for gain when milk replacers are used in calves' diets.

\section{Protein Requirements}

Fecal Metabolic Nitrogen Fraction. The intercept of the relationship between apparent $\mathrm{N}$ absorbed and $\mathrm{N}$ intake differed $(P<0.01)$ between groups that did not receive (Figure 3A) or did receive (Figure 3B) starter feed in the diet, with values of $-0.073 \pm 0.0364$ and $-0.089 \pm 0.0858 \mathrm{~g} / \mathrm{BW}^{0.75}$ per d, respectively. Therefore, based on the proportion of milk and starter in the diets and their $\mathrm{N}$ contents, the MFN was estimated as $0.073 \mathrm{~g} / \mathrm{BW}^{0.75}$ per d for milk, and $0.125 \mathrm{~g} / \mathrm{BW}^{0.75}$ per $\mathrm{d}$ for starter feed.

The metabolic fraction is usually assumed to be directly correlated with DMI (NRC, 2001). In calves' diets, other elements may be as important as the level of intake, including the presence or absence of starter feed. The NRC (2001) assumed a MFN for milk replacer and for starter feed of MR of 1.9 and $3.3 \mathrm{~g} / \mathrm{kg}$ of DMI. The relative increase in MFN of starter feed compared with milk replacer of NRC (1.74) is close to
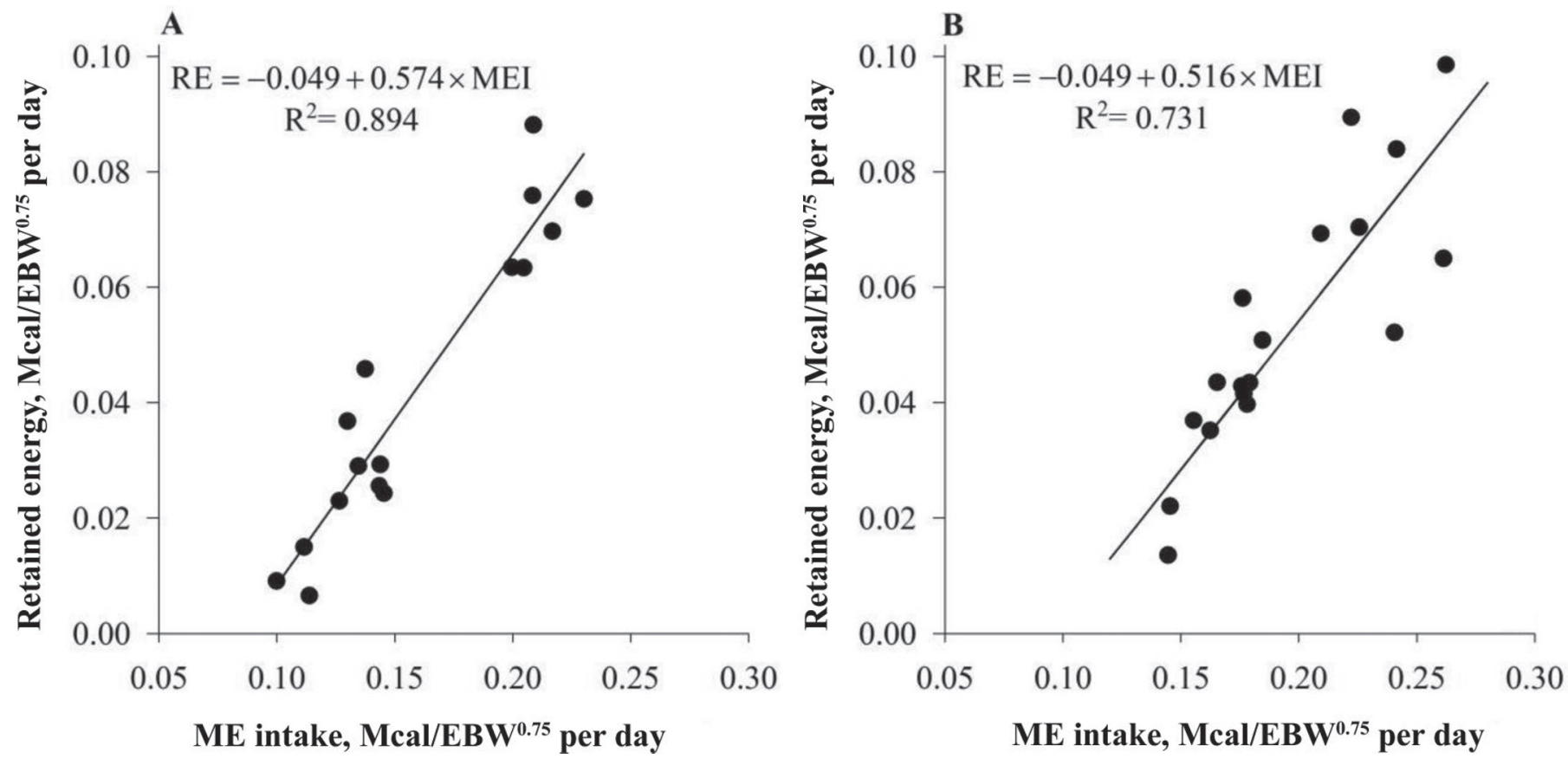

Figure 2. Relationship between retained energy (RE) and metabolizable energy intake (MEI) for animals consuming only milk (A) or milk plus starter (B). 

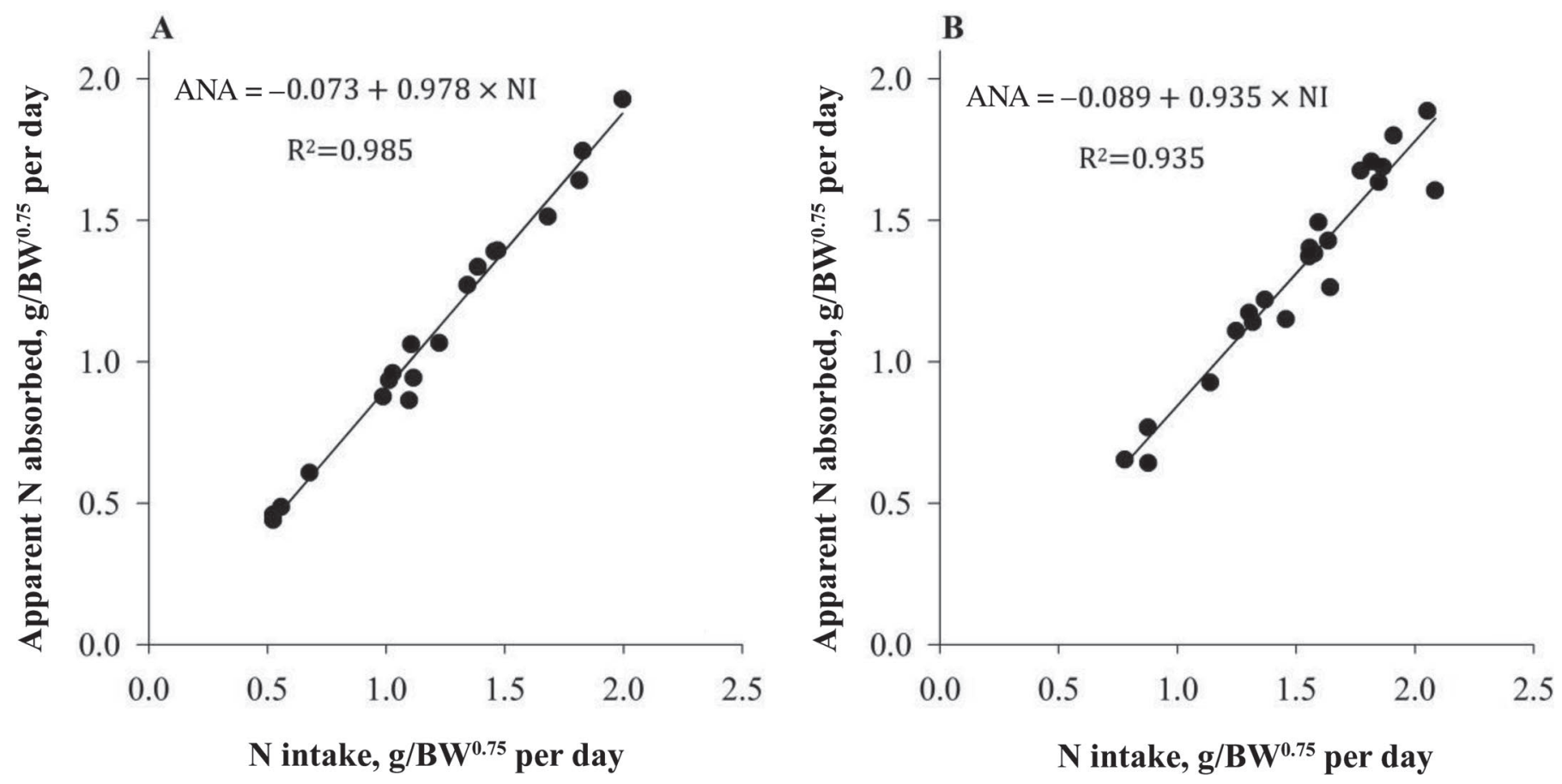

Figure 3. Relationship between apparent $\mathrm{N}$ absorbed (ANA) and $\mathrm{N}$ intake (NI), as a function of metabolic weight, for animals consuming only milk (A) or milk plus starter (B).

that in the present study (1.71). The present results suggest that inclusion of starter feed increases fecal $\mathrm{N}$ content, thus underestimating the true digestibility of this fraction, and consequently biasing the intake of metabolizable protein.

Protein Requirements for Maintenance. The net protein requirement for maintenance was not affected by inclusion of starter feed in the $\operatorname{diet}(P>$ $0.453)$ and was $2.33 \mathrm{~g} / \mathrm{EBW}^{0.75}$ per d:

$$
\begin{aligned}
& \mathrm{RP}=-2.33 \pm 0.801+0.77 \pm 0.085 \times \mathrm{MPI} \\
& \left(\mathrm{R}^{2}=0.714 ; \mathrm{RMSE}=0.463\right)
\end{aligned}
$$

where RP and MPI are in grams/EBW ${ }^{0.75}$ per day. This value is close to the values of 2.30 and $2.69 \mathrm{~g} / \mathrm{EBW}^{0.75}$ per d for adult animals suggested by the AFRC (1993) and by Valadares Filho et al. (2006), respectively.

The metabolizable protein for maintenance requirement, calculated as the ratio between the intercept of Equation [19] and the average metabolic live weight of the animals $(18.4 \mathrm{~kg})$, was $3.52 \pm 0.34 \mathrm{~g} / \mathrm{BW}^{0.75}$ per $\mathrm{d}$.

$$
\begin{aligned}
& \mathrm{MPI}=64.83 \pm 6.242+168.11 \pm 10.743 \times \mathrm{ADG} \\
& \left(\mathrm{R}^{2}=0.887 ; \mathrm{RMSE}=0.176\right),
\end{aligned}
$$

Although this value is somewhat below the 3.8 and $4.0 \mathrm{~g} / \mathrm{kg}$ of $\mathrm{BW}^{0.75}$ per $\mathrm{d}$ reported for adult animals by NRC (2000) and Valadares Filho et al. (2010), respectively, the use of this method appears to be a better alternative than the use of the factorial method adopted by NRC (2001), because the factorial method underestimates N losses (Hauschild et al., 2010) and, consequently, protein requirements.

The efficiency of use of MP for maintenance was 66.2 $\pm 0.42 \%$. According to Oldham (1987), an ideal mixture of AA should have an efficiency of $85 \%$, but for Zinn and Owens (1983) this value would be $66 \%$. However, many values lower than these expected efficiencies are found for mature animals, varying around 50\% (NRC, 2000; Valadares Filho et al., 2010). The AA profile of calf's body tissues is similar to the AA profile of milk (Oldham, 1987), which may potentially lead to a high efficiency of use of dietary protein for maintenance, resulting in a lower MP requirement compared with diets with a lower biological value of protein.

Requirements and Efficiency of Use of Protein for Gain. The body protein content was not affected by the starter feed inclusion $(P>0.512)$, and the given allometric model was

$$
\mathrm{BP}=0.1117 \pm 0.0142 \times \mathrm{EBW}^{1.0663 \pm 0.0295},
$$


where $\mathrm{BP}=$ body protein $(\mathrm{kg})$ and $\mathrm{EBW}=\mathrm{EBW}(\mathrm{kg})$. Taking the first derivate of Equation [20] (as described in Equation [13]), the $\mathrm{NP}_{\mathrm{g}}$ was obtained:

$$
\begin{aligned}
& \mathrm{NP}_{\mathrm{g}}=119.1 \pm 32.9 \times \mathrm{EBW}^{0.0663 \pm 0.059} \\
& \left(\mathrm{R}^{2}=0.872 ; \mathrm{RMSE}=1.258\right),
\end{aligned}
$$

where $\mathrm{NP}_{\mathrm{g}}$ is in grams/EBG per day and $\mathrm{EBW}$ is in kilograms.

The coefficient associated with EBW implies that as the EBW of the animals is increased, they tend to require more protein for weight gain. Carvalho et al. (2003) and Nascimento et al. (2009) observed a similar response for the requirements of protein for gain and correlated this fact with the body composition of the animals, because in this stage of life protein has a greater proportion in relation to the other body tissues (Berge, 1991).

Unlike what was observed by Labussiere et al. (2009), the inclusion of starter feed in the diet did not affect $(P>0.83)$ the efficiency of use of MP for gain $(k)$, which, in the current study, was $77 \pm 8.5 \%$ (Figure 4). The NRC (2001) suggests a $k$ of the order of $80 \%$ with calves, whereas the studies of Blome et al. (2003) and Bartlett et al. (2006) showed protein gain efficiency values to be somewhat lower: 66 and $74 \%$, respectively. The differences found in relation to NRC (2001) may be linked to methodological aspects, given that the NRC (2001) data are calculated by the factorial method, whereas the other data derive from comparative slaughter technique experiments. It is known that the factorial method may underestimate $\mathrm{N}$ losses (Hauschild et al., 2010) and consequently overestimate the efficiency of use of protein.

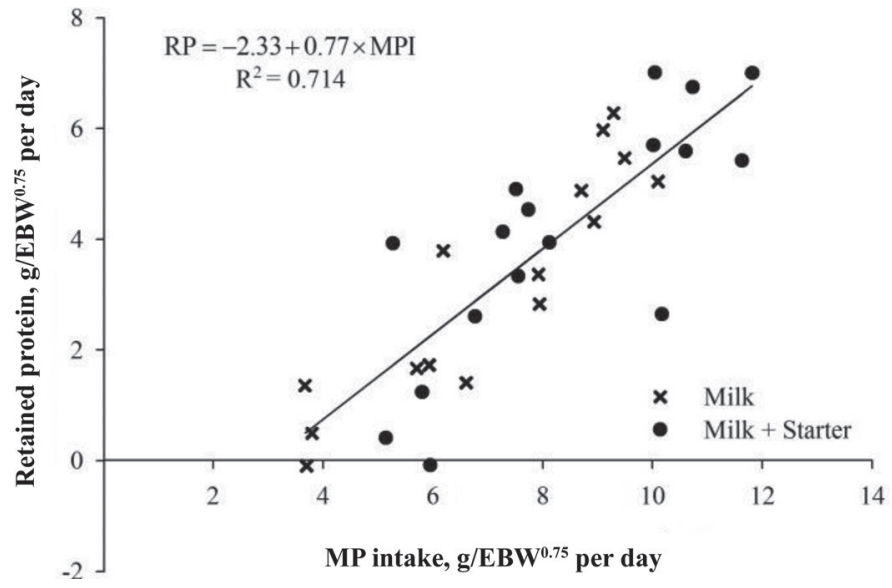

Figure 4. Relationship between retained protein (RP) and metabolizable protein intake (MPI).

\section{CONCLUSIONS}

The results obtained here may be used to estimate the nutrient requirements of Holstein $\times$ Gyr crossbred calves in the preweaned phase. In addition, the comparison between presented data and the literature indicates differences between Holstein $\times$ Gyr crossbred and pure Holstein animals, and emphasizes the need for new studies aiming to provide a better understanding of these differences. The efficiency of use of ME for gain, but not for maintenance, with milk-only diets was greater than that when starter feed was included in the diet, which should be considered during diet formulation. The net protein required for gain increases with EBW, but the inclusion of starter feed in the diet did not affect the use of MP for gain.

\section{ACKNOWLEDGMENTS}

We are grateful to the following Brazilian foundations: Coordenação de Aperfeiçoamento de Pessoal de Nível Superior (CAPES), Conselho Nacional de Desenvolvimento Científico e Tecnológico $(\mathrm{CNPq})$, Fundação de Amparo à Pesquisa do Estado de Minas Gerais (FAPEMIG), and Instituto de Ciência e Tecnologia de Ciência Animal (INCT-CA) for supporting this study.

\section{REFERENCES}

AFRC. 1993. Energy and Protein Requirements of Ruminants. G. Alderman, ed. Agricultural and Food Research Council. CAB International, Wallingford, UK.

Agricultural Research Council (ARC). 1980. The Nutrient Requirements of Ruminant Livestock. Agricultural Research Council, The Gresham Press, London, UK.

Arieli, A., J. W. Schrama, W. Van der Hel, and M. W. Verstegen. 1995. Development of metabolic partitioning of energy in young calves. J. Dairy Sci. 78:1154-1162. https://doi.org/10.3168/jds. S0022-0302(95)76732-7.

Bach, A., and J. Ahedo. 2008. Record keeping and economics of dairy heifers. Vet. Clin. North Am. Food Anim. Pract. 24:117-138. https://doi.org/10.1016/j.cvfa.2007.10.001.

Bartlett, K. S., F. K. McKeith, M. J. VandeHaar, G. E. Dahl, and J. K. Drackley. 2006. Growth and body composition of dairy calves fed milk replacers containing different amounts of protein at two feeding rates. J. Anim. Sci. 84:1454-1467.

Berge, P. 1991. Long-term effects of feeding during calfhood on subsequent performance in beef cattle (a review). Livest. Prod. Sci. $28: 171-201$.

Blome, R. M., J. K. Drackley, F. K. Mckeith, M. F. Hutjens, and G. C Mccoy. 2003. Growth, nutrient utilization, and body composition of dairy calves fed milk replacers containing different amounts of protein. J. Anim. Sci. 81:1641-1655.

Carvalho, P. A., L. M. Bonnecarrère Sanchez, C. C. Pires, J. Viégas, J. P. Velho, and W. Paris. 2003. Composição corporal e exigências líquidas de proteína e energia para ganho de peso de bezerros machos de origem leiteira do nascimento aos 110 dias de idade. Rev. Bras. Zootec. 32:1484-1491. https://doi.org/10.1590/S151635982003000600024 .

Chizzotti, M. L., L. O. Tedeschi, and S. C. Valadares Filho. 2008. A meta-analysis of energy and protein requirements for maintenance 
and growth of Nellore cattle. J. Anim. Sci. 86:1588-1597. https:// doi.org/10.2527/jas.2007-0309.

Chizzotti, M. L., S. C. Valadares Filho, L. O. Tedeschi, F. H. M. Chizzotti, and G. E. Carstens. 2007. Energy and protein requirements for growth and maintenance of F1 Nellore x Red Angus bulls, steers, and heifers. J. Anim. Sci. 85:1971-1981. https://doi. org $/ 10.2527 /$ jas.2006-632.

CSIRO. 2007. Nutrient Requirements of Domesticated Ruminants. Commonwealth Scientific and Industrial Research Organization, Collingwood, VIC, Australia.

Detmann, E., and S. C. Valadares Filho. 2010. On the estimation of non-fibrous carbohydrates in feeds and diets. Arq. Bras. Med. Vet. Zootec. 62:980-984.

Diaz, M. C., M. E. Van Amburgh, J. M. Smith, J. M. Kelsey, and E. L. Hutten. 2001. Composition of growth of Holstein calves fed milk replacer from birth to 105-kilogram body weight. J. Dairy Sci. 84:830-842. https://doi.org/10.3168/jds.S0022-0302(01)74541-9.

Ferrell, C. L., and T. G. Jenkins. 1998a. Body composition and energy utilization by steers of diverse genotypes fed a high-concentrate diet during the finishing period: I. Angus, Belgian Blue, Hereford, and Piedmontese sires. J. Anim. Sci. 76:637-646.

Ferrell, C. L., and T. G. Jenkins. 1998b. Body composition and energy utilization by steers of diverse genotypes fed a high-concentrate diet during the finishing period: II. Angus, Boran, Brahman, Hereford, and Tuli sires. J. Anim. Sci. 76:647-657.

Fonseca, M. A., S. de C. Valadares Filho, L. T. Henriques, P. V. R. Paulino, E. Detmann, E. A. Fonseca, P. D. B. Benedeti, and L. D. da Silva. 2012. Exigências nutricionais de bezerros nelores lactentes. Rev. Bras. Zootec. 41:1212-1221. https://doi.org/10.1590/ S1516-35982012000500019.

Fortin, A., S. Simpfendorfer, J. T. Reid, H. J. Ayala, R. Anrique, and A. F. Kertz. 1980. Effect of level of energy intake and influence of breed and sex on the chemical composition of cattle. J. Anim. Sci. 51:604-614.

Garrett, W. N. 1980. Energy utilization by growing cattle as determined in 72 comparative slaughter experiments. Pages $3-7$ in Proc 8th Symposium of Energy Metabolism. London, UK. University of Cambridge, Cambridge, UK.

Garrett, W. N., and D. E. Johnson. 1983. Nutritional energetics of ruminants. J. Anim. Sci. 57:478-497.

Gelsinger, S. L., A. J. Heinrichs, and C. M. Jones. 2016. A metaanalysis of the effects of preweaned calf nutrition and growth on first-lactation performance. J. Dairy Sci. 99:6206-6214. https:// doi.org/10.3168/jds.2015-10744

Gerrits, W. J., G. H. Tolman, J. W. Schrama, S. Tamminga, M. W. Bosch, and M. W. Verstegen. 1996. Effect of protein and proteinfree energy intake on protein and fat deposition rates in preruminant calves of 80 to $240 \mathrm{~kg}$ live weight. J. Anim. Sci. 74:2129-2139.

Hauschild, L., C. Pomar, and P. A. Lovatto. 2010. Systematic comparison of the empirical and factorial methods used to estimate the nutrient requirements of growing pigs. Animal 4:714-723. https:// doi.org/10.1017/S1751731109991546.

Holmes, C. W., and A. W. F. Davey. 1976. The energy metabolism of young Jersey and Friesian calves fed fresh milk. Anim. Prod. 23:43-53. https://doi.org/10.1017/S0003356100031068.

INRA. 2007. Alimentation des bovins, ovins et caprins. Besoins des animaux. Valeurs des aliments. J. Agabriel, ed. Editions Quae, Versailles, France.

Khan, M. A., D. M. Weary, M. A. G. Von Keyserlingk, and M. A. G. von Keyserlingk. 2011. Invited review: Effects of milk ration on solid feed intake, weaning, and performance in dairy heifers. J. Dairy Sci. 94:1071-1081. https://doi.org/10.3168/jds.2010-3733.

Kohn, R. A., M. M. Dinneen, and E. Russek-Cohen. 2005. Using blood urea nitrogen to predict nitrogen excretion and efficiency of nitrogen utilization in cattle, sheep, goats, horses, pigs, and rats. J. Anim. Sci. 83:879-889.
Labussiere, E., S. Dubois, J. van Milgen, G. Bertrand, and J. Noblet. 2009. Effect of solid feed on energy and protein utilization in milk-fed veal calves. J. Anim. Sci. 87:1106-1119. https://doi. org $/ 10.2527 /$ jas.008-1318.

Moallem, U., D. Werner, H. Lehrer, M. Zachut, L. Livshitz, S. Yakoby, and A. Shamay. 2010. Long-term effects of ad libitum whole milk prior to weaning and prepubertal protein supplementation on skeletal growth rate and first-lactation milk production. J. Dairy Sci 93:2639-2650. https://doi.org/10.3168/jds.2009-3007.

Nascimento, P. V. N., F. F. da Silva, C. M. Veloso, P. Bonomo, F. A. Teixeira, and J. Gonsalves Neto. 2009. Exigências nutricionais de bezerros da raça Holandesa alimentados com concentrado e feno de capim-elefante. Rev. Bras. Zootec. 38:1605-1613. https://doi. org/10.1590/S1516-35982009000800027.

NRC. 2000. Nutrient Requirements of Beef Cattle. 7th ed. National Academy Press, Washington, DC.

NRC. 2001. Nutrient Requirements of Dairy Cattle. 7th ed. National Academy Press, Washington, DC.

Oldham, J. D. 1987. Efficiencies of amino acid utilization. Pages 171-186 in Feed Evaluation and Protein Requirement Systems for Ruminants. R. Jarrige and G. Alderman, ed. Commission of the European Communities, Brussels.

Ruas, J. R. M., R. Amaral, J. J. Ferreira, and A. Marcatti Neto. 2006. Produção integrada de leite e carne bovina. Pages 511-528 in Anais do V Simpósio de Produção de Gado de Corte e I Simpósio Internacional de Produção de Gado de Corte. F. C. Figueiredo, K. A. Magalhães, L. V Barros, L. C. Diniz, M. I. Marcondes, M. L. Chizzotti, M. A. Fonseca, P. D. B. Benedeti, M. F. Paulino, and S. C. Valadares Filho, ed. Suprema gráfica e editora Ltda., Viçosa-MG, Brazil

Schrama, J. W., W. van der Hel, A. Arieli, and M. W. Verstegen. 1992 Alteration of energy metabolism of calves fed below maintenance during 6 to 14 days of age. J. Anim. Sci. 70:2527-2532.

Signoretti, R. D., J. F. C. Silva, S. C. Valadares Filho, J. C. Pereira, G. G. L. Araújo, P. R. Cecon, and A. C. Queiroz. 1999. Eficiência de utilização da Eficiência de Utilização da Energia Metabolizável para Ganho de Peso e Exigências de Energia Metabolizável, Nutrientes Digestíveis Totais e Proteína Metabolizável de Bezerros da Raça Holandesa. Rev. Bras. Saúde e Produção Anim. 28:214-221.

Silva, A. L., M. I. Marcondes, E. Detmann, F. S. Machado, S. C Valadares Filho, A. S. Trece, and J. Dijkstra. 2015. Effects of raw milk and starter feed on intake and body composition of Holstein $\times$ Gyr male calves up to 64 days of age. J. Dairy Sci. 98:26412649. https://doi.org/10.3168/jds.2014-8833.

Soberon, F., E. Raffrenato, R. W. Everett, and M. E. Van Amburgh. 2012. Preweaning milk replacer intake and effects on long-term productivity of dairy calves. J. Dairy Sci. 95:783-793. https://doi. org/10.3168/jds.2011-4391.

Toullec, R. 1989. Veal calves. In Ruminant Nutrition-Recommended Allowances and Feed Tables. R. Jarrige, ed. INRA, John Libby, London, UK.

Valadares Filho, S. C., M. I. Marcondes, M. L. Chizzotti, and P. V. R. Paulino. 2010. Exigências nutricionais de zebuínos puros e cruzados-BR-CORTE. 2nd ed. Suprema Gráfica e Editora Ltda., Viçosa, MG, Brazil.

Valadares Filho, S. C., P. V. R. Paulino, and K. A. Magalhães. 2006 Exigências nutricionais de zebuínos e tabelas de composição de alimentos-BR CORTE. 1st ed. Suprema Grafica Ltda., Viçosa, MG, Brazil.

Wilkerson, V. A., T. J. Klopfenstein, R. A. Britton, R. A. Stock, and P. S. Miller. 1993. Metabolizable protein and amino acid requirements of growing cattle. J. Anim. Sci. 71:2777-2784.

Zinn, R. A., and F. N. Owens. 1983. Influence of feed intake level on site of digestion in steers fed a high concentrate diet. J. Anim. Sci. $56: 471-475$. 